\title{
PENILAIAN TINGKAT KESEHATAN BANK: PENDEKATAN CAMEL DAN RGEC
}

\author{
(Studi Pada Bank Maybank Syariah Indonesia Periode 2011-2016)
}

\author{
Erika Amelia dan Astiti Chandra Aprilianti \\ Syarief Hidayatullah State Islamic University of Jakarta \\ Email: astitichandra26@gmail.com \\ DOI: https://doi.org/10.5281/jakis.v6i2.116
}

\begin{abstract}
.
This study aims to determine the risk based bank rating at PT. Bank Maybank Syariah Indonesia if measured using CAMEL (Capital, Asset, Management, Earning, Liquidity) method and RGEC (Risk Profile, Good Corporate Governance, Earning, Capital) in 2011-2016 and also aims to know differences in ratios used in CAMELS and RGEC methods. The research method used in this research is literature research or study desk study. The data used in this research is secondary data using financial statements of Bank Maybank Syariah Indonesia Period 2011-2016. The results show that the bank can be said to be adequately sound because almost all the ratios used meet the specified requirements and there are still some ratios that have not met the requirements, but in both methods have different results. In the year 2011-2014 the risk based bank rating of Maybank Syariah Bank is calculated using CAMEL method of bank is in the sound level. In 2015 -2016, the calculation of bank soundness shows that bank condition is in an sound level. In Maybank Syariah Bank the state of the bank is in the sound level is in 2011-2013 if calculated using the RGEC method. In the year 2014-2016 the condition of the bank shows a adequately sound level.
\end{abstract}

Keywords: $\quad C A M E L, R G E C, R B B R$, Bank performance

\section{PENDAHULUAN}

Salah satu perusahaan yang menjual jasa adalah perusahaan yang bergerak dalam bidang perbankan atau lebih dikenal dengan nama Bank. Bank merupakan perusahaan yang menyediakan jasa keuangan bagi seluruh lapisan masyarakat. Fungsi bank merupakan perantara di antara masyarakat yang membutuhkan dana dengan masyarakat yang kelebihan dana, di samping menyediakan jasa-jasa keuangan lainnya. Oleh karena bank berfungsi sebagai perantara keuangan, maka dalam hal ini faktor "kepercayaan" dari masyarakat merupakan faktor utama dalam menjalankan bisnis perbankan (Kasmir, 2000)

Pada era tahun 1980-an dan era 1990-an bisnis perbankan mulai aktif mengejar nasabah. Puluhan bank baru berdiri hal ini disebabkan oleh kesempatan yang diberikan pemerintah untuk mendirikan bank begitu mudah misalnya dengan modal Rp. 50.000.000,- setiap orang dapat mendirikan BPR (Kasmir, 2000) Sehingga bank baru banyak bermunculan dan membuat perbankan Indonesia tumbuh subur. Kemudian pada tahun 1997-2000 
merupakan kehancuran dunia perbankan Indonesia. Puluhan Bank di likuidasi dan puluhan lainnya dimerjer.

Salah satu bank yang tetap bertahan ketika Bank lainnya dimerjer dan dilikuidasi adalah Bank Muamalat Indonesia (BMI) sebagai pelopor perbankan syariah pada tahun 1998 yang mampu bertahan beriringan dengan krisis moneter yang sedang terjadi sehingga perbankan syariah menjadi salah satu solusi bagi masyarakat untuk menyimpan dana yang ia miliki maupun solusi alternatif bagi perbankan konvensional untuk menggunakan sistem syariah dan pada tahun 1999 berdirilah bank syariah kedua di Indonesia yaitu Bank Syariah Mandiri yang merupakan anak perusahan Bank Mandiri (Ismail, 2011)

Pemerintah juga memberi perhatian terhadap perkembangan Bank Syariah hal ini dibuktikan dengan dibuatnya Undang Undang Nomor 21 tahun 2008 tentang Perbankan Syariah yang mencakup Bank Umum Syariah, Unit Usaha Syariah dan Bank Pembiayaan Rakyat Syariah Dalam kurun waktu 17 tahun, bank syariah mengalami perkembangan yang sangat signifikan, meskipun secara nasional market share bank syariah masih rendah dibandingkan dengan bank konvensional (Ismail, 2011)

Namun lembaga Perbankan syariah mengalami perkembangan yang cukup pesat, perkembangan perbankan syariah dari sisi kelembagaan mengalami perubahan yang fluktuatif, pada tahun 2011 sampai 2013 Bank Umum Syariah atau disebut BUS di Indonesia berjumlah 11 unit dan pada tahun 2014 sampai dengan 2015 bertambah satu unit menjadi 12 unit. Sedangkan pada unit usaha syariah pada tahun 2013 mengalami penurunan dari 24 unit menjadi 23 unit diikuti tahun 2014-2015 unit usaha syariah terus turun 22 unit penurunan ini disebabkan oleh beberapa faktor salah satunnya dengan adanya spin off unit usaha syariah menjadi BUS seperti yang terjadi pada Bank Tabungan Pensiunan Nasional Syariah (BTPNS) yang pada awalnya merupakan unit usaha syariah.

Pada Bank Pembiayaan Rakyat Syariah (BPRS) cenderung fluktuatif pada tahun 2011 berjumlah 155 unit kemudian mengalami peningkatan pada tahun 2012 sejumlah 158 unit dan terus meningkat pada tahun 2013-2014 hingga 163 unit dan pada tahun 2015 BPRS mengalam penurunan hingga 162 unit. Pada tahun akhir tahun 2016 UUS BPD Aceh bergabung menjadi BUS yaitu Bank Aceh Syariah sehingga jumlah UUS berkurang menjadi 21 unit namun BUS bertambah menjadi 13 unit, namun fenomena persaingan merupakan hal yang tidak bisa dihindari antara bank syariah dan bank konvensional ditambah dengan rendahnya market share bank syariah sehingga industri perbankan syariah dituntut untuk memiliki kinerja yang baik, kuat serta efisien agar mampu bersaing dan terus mendapatkan kepercayaan dari nasabah.

Dengan itu BI juga semakin memperketat dalam pengaturan dan pengawasan perbankan nasional, karena BI tidak ingin mengulangi peristiwa di awal krisis ekonomi pada tahun 1997 dimana banyak bank dilikuidasi karena kinerjanya tidak sehat, yang pada akhirnya merugikan masyarakat (Kusumo, 2008). Ada beberapa metode yang digunakan untuk mengukur 
tingkat kesehatan Bank Syariah salah satunya menggunakan pendekatan Peraturan Bank Indonesia No. 9/1/PBI/2007. Unsur -unsur yang harus ada dalam penilaian ini adalah kecukupan modal (Capital), kualitas aset (Assets), kualitas manajemen (Management), rentabilitas (Earnings), likuiditas (Liquidity), sensitifitas terhadap risiko pasar (Sensitivity to Market Risk). Penilaian tingkat kesehatan ini disebut juga dengan metode CAMELS (Darmawi, 2011)

Namun sejalan dengan perkembangan sektor perbankan syariah yang semakin kompleks maka penilaian kesehatan perbankan perlu ditambahkan dengan penerapan manajemen risiko dan good corporate governance dimana dalam metode CAMELS belum mencakup kedua hal tersebut.Dengan demikian Bank Indonesia yang pada saat itu menjadi pengawas pada perbankan melengkapi metode penilaian kesehatan pada bank dengan memperbaharui Peraturan Bank Indonesia PBI No.9/1/PBI/2007 yang berisi tentang metode penilaian kesehatan Bank Syariah dengan menggunakan metode CAMELS menjadi PBI No.13/1/PBI/2011 tentang penilaian tingkat kesehatan bank dengan menggunakan pendekatan risiko (Risk-Based bank rating/RBBR) yang selanjutnya disebut dengan metode RGEC. Indikator penilaian kesehatan bank dalam metode RGEC terdiri dari Risk (R), Good Corporate Governance (G), Earnings (E) dan Capital (C). Kemudian dari empat indikator tersebut penilaian dilakukan dengan cara dibandingkan dengan peringkat komposit (PK) pada masing-masing rasio (PBI No. 13/1/PBI/2011) Peringkat tersebut terdiri dari kriteria penilaian yaitu sangat sehat, sehat, cukup sehat, kurang sehat, dan tidak sehat.

Penelitian ini dilakukan di PT Bank Maybank Syariah Indonesia karena bank tersebut pada tahun 2015 mengalami penurunan total aset sebesar Rp. 1,743 triliun dari Rp. 2,44 triliun pada tahun 2014 (Laporan Tahunan Maybank Syariah 2017, 2017). Dilihat dari rasio kecukupan modalnya pun bank tersebut cenderung mengalami penurunan setiap tahunnya dan pendapatan marjin jual beli yang juga ikut menurun dari 131,7 Milyar menjadi 127,7 Milyar kemudian pada tahun 2016 Total aset sebesar Rp1,34 triliun, turun 22,9\% dibandingkan dengan tahun sebelumnya. Pembiayaan juga mengalami penurunan sebesar 38\% menjadi Rp962,86 miliar dan Dana Pihak Ketiga (DPK) mengalami penurunan sebesar 23,9\% menjadi Rp714.72 miliar dari data tersebut ditakutkan munculnya krisis kepercayaan dari nasabah sehingga perlu untuk ditinjau bagaimana keadaan kesehatan bank tersebut.

Berikut dilampirkan keadaan rasio keuangan PT Bank Maybank Syariah Indonesia periode 2011-2016

Tabel 1. Rasio Keuangan Bank Maybank Syariah 2011-2016

\begin{tabular}{ccccccc}
\hline Rasio $\%$ & 2011 & 2012 & 2013 & 2014 & 2015 & 2016 \\
\hline CAR & $73,44 \%$ & $63,98 \%$ & $59,41 \%$ & $52,13 \%$ & $38,40 \%$ & $55,06 \%$ \\
\hline NPF & $4,93 \%$ & $4,29 \%$ & $0,00 \%$ & $1,25 \%$ & $0,00 \%$ & $4,60 \%$ \\
\hline ROA & $3,57 \%$ & $2,88 \%$ & $2,87 \%$ & $3,61 \%$ & $(20,13 \%)$ & $(9,51 \%)$ \\
\hline NOM & - & - & - & $(1,46 \%)$ & $(32,92 \%)$ & $(19,96 \%)$ \\
\hline
\end{tabular}




\begin{tabular}{ccccccc}
\hline BOPO & $55,18 \%$ & $53,77 \%$ & $67,79 \%$ & $69,60 \%$ & $192,60 \%$ & $160,28 \%$ \\
\hline FDR & $289,20 \%$ & $197,70 \%$ & $152,87 \%$ & $157,77 \%$ & $110,54 \%$ & $134,73 \%$ \\
\hline \multicolumn{6}{c}{ Sumber Laporan Keuangan Tahunan PT Maybank Syariah Indonesia 2011-2016 }
\end{tabular}

Mengingat lembaga perbankan sebagai lembaga penghimpun dana dari masyarakat luas dan memerlukan kepercayaan dari masyarakat yang menyimpan dananya di bank, untuk itu menjaga kesehatan bank dirasa penting untuk mempertahankan kepercayaan masyarakat. Maka dari itu peneliti mengangkat tema mengenai penilaian kesehatan bank menggunakan analisis komparatif dua metode yaitu metode CAMEL dan RGEC pada Bank Maybank Syariah Indonesia periode 2011-2016.

\section{KAJIAN TEORI}

\subsection{KESEHATAN BANK}

Kesehatan bank merupakan kepentingan semua pihak terkait, baik pemilik, manajemen bank, masyarakat pengguna jasa bank, Bank Indonesia dan Otoritas Jasa Keuangan selaku otoritas pengawasan perbankan dan pemerintah. Karena kegagalan perbankan akan berakibat buruk terhadap perekonomian (Darmawi, 2011, hal. 210). Tingkat Penilaian Kesehatan pada bank umum diatur dalam PBI Nomor 13/1/PBI/2011 tentang penilaian kesehatan bank berdasarkan profil risiko sebagai penyempurnaan dari PBI Nomor 9/1/PBI/2007. Peraturan ini diperbaharui karena semakin berkembangnya bisnis perbankan sehingga masalah yang dialami oleh lembaga perbankan semakin kompleks sehingga berpengaruh terhadap risiko kemudian akan berpengaruh pula pada tingkat kesehatan bank diperlukan sistem penilaian yang detai dan akurat. Menurut Peraturan Bank Indonesia Nomor 13/1/PBI/2011 Kesehatan Bank harus dipelihara atau ditingkatkan agar kepercayaan masyarakat terhadap Bank dapat tetap terjaga. Selain itu, Tingkat Kesehatan Bank digunakan sebagai salah satu sarana dalam melakukan evaluasi terhadap kondisi dan permasalahan yang dihadapi Bank serta menentukan tindak lanjut untuk mengatasi kelemahan atau permasalahan Bank.

\subsection{METODE CAMEL}

Metode ini merupakan suatu alat ukur yang digunakan untuk menentukan suatu kondisi Bank sebagaimana tertera pada Peraturan Bank Indonesia Nomor 9/1/PBI/2007 tentang sistem penilaian tingkat kesehatan bank umum berdasarkan prinsip syariah, terdiri dari aspek permodalan (Capital), aspek kualitas asset (Assets), aspek kualitas manajemen (Management), aspek rentabilitas (Earnings), aspek likuiditas (Liquidity), aspek sensitifitas pada risiko pasar (Sensitivity to Market Ratio). 


\subsubsection{Penilaian Aspek Permodalan (Capital)}

Dalam aspek ini yang dinilai adalah permodalan yang dimiliki oleh bank yang didasarkan kepada kewajiban penyediaan modal minimum bank. Penilaian tersebut didasarkan kepada CAR (Capital Adequacy Ratio) yang telah ditetapkan oleh Bank Indonesia (Kasmir, 2004). Perbandingan rasio CAR adalah rasio modal terhadap Aktiva Tertimbang Menurut Resiko (ATMR). Sesuai ketentuan yang telah ditetapkan pemerintah, maka CAR perbankan untuk tahun 2002 batas minimalnya adalah 8\%, bagi bank yang memiliki CAR dibawah $8 \%$ harus segera memperoleh perhatian yang serius untuk segera diperbaiki.

\subsubsection{Penilaian Kualitas Aset (Assets)}

Aspek yang selanjutnya perlu dinilai adalah aspek kualitas terhadap jenisjenis aset yang dimiliki oleh bank. Penilaian aset harus sesuai dengan peraturan Bank Indonesia, yaitu meliputi komponen-komponen sebagai berikut: $(6 / 10 / \mathrm{PBI} / 2004)$

a. Kualitas aktiva produktif, konsentrasi eksposur risiko kredit, perkembangan aktiva produktif bermasalah, dan kecukupan penyisihan penghapusan aktiva produktif (PPAP)

b. Kecukupan kebijakan dan prosedur, system kaji ulang (review) internal, system dokumentasi, dan kinerja penanganan aktiva produktif bermasalah.

Rasio- rasio tersebut dapat dilihat dari neraca yang telah dilaporkan secara berkala kepada Bank Indonesia.

\subsubsection{Penilaian Aspek Kualitas Manajemen (Management)}

Penilaian yang ketiga meliputi penilaian kualitas manajemen bank. Untuk menilai kualitas bank dapat dilihat dari kualitas manusianya dalam mengelola bank namun dalam aspek ini yang dinilai adalah manajemen permodalan, manajemen kualitas aktiva, manajemen umum, manajemen rentabilitas, dan manajemen likuiditas. Penilaian selanjutnya yang dinilai dalam aspek manajemen adalah kepatuhan bank terhadap ketentuan yang berlaku dan komitmen kepada Bank Indonesia atau pihak lainnya. Merkusiwati (2007) dalam penelitiannya menggambarkan tingkat kesehatan bank dari aspek manajemen melalui rasio Net Profit Margin (NPM), alasannya karena seluruh kegiatan manajemen suatu bank yang mencakup manajemen umum, manajemen resiko dan kepatuhan bank pada akhirnya akan mempengaruhi dan bermuara pada perolehan laba.

\subsubsection{Penilaian Aspek Rentabilitas (Earnings)}

Penilaian aspek rentabilitas merupakan aspek yang digunakan untuk mengukur kemampuan bank dalam meningkatkan keuntungan. Kemampuan ini dilakukan dalam suatu periode. Kegunaan aspek ini juga untuk mengukur tingkat efisiensi usaha dan profitabilitas yang dicapai oleh bank yang bersangkutan. Bank yang sehat adalah bank yang jika diukur secara 
rentabilitas terus berada dan meningkat diatas standar yang telah ditetapkan. (Kasmir, 2004, hal. 4) Komponen-komponen yang dinilai dalam aspek rentabilitas adalah sebagai berikut: (6/10/PBI/2004)

a. Pencapaian return on assets (ROA), return on equity (ROE), net interest margin (NIM), dan tingkat efisiensi bank.

b. Perkembangan laba operasional, diversifikasi pendapatan, penerapan prinsip akuntansi dalam pengakuan pendapatan dan biaya, dan prospek laba operasional.

\subsubsection{Penilaian Aspek Likuiditas (Liquidity)}

Suatu bank dapat dikatakan likuid, apabila bank yang bersangkutan mampu membayar semua hutangnya terutama hutang-hutang jangka pendek. Dalam hal ini yang dimaksud hutang jangka pendek adalah simpanan masyarakat seperti simpanan tabungan, giro dan deposito. Dikatakan likuid jika pada saat ditagih bank mampu membayar. (Kasmir, 2004, hal. 44-45) Komponenkomponen yang dinilai dalam aspek ini adalah:

a. Rasio aktiva atau pasiva likuid, potensi maturity mismatch, kondisi Loan to Deposit Ratio (LDR), proyeksi cash flow, dan konsentrasi pendanaan.

b. Kecukupan kebijakan dan pengelolaan likuiditas (assets and liabilities management/ALMA), akses kepada sumber pendanaan dan stabilitas pendanaan

\subsubsection{Penilaian Aspek Sensitifitas terhadap Risiko Pasar}

Penilaian ini dimaksudkan untuk menilai kemampuan keuangan bank dalam mengantisipasi perubahan risiko pasar yang disebabkan oleh pergerakan nilai tukar. Penilaian sensitivitas atas risiko pasar dilakukan dengan menilai besarnya kelebihan modal yang digunakan untuk menutup risiko bank dibandingkan dengan besarnya risiko kerugian yang timbul dari pengaruh perubahan risiko pasar (Ihsan, 2015).

Hasil penilaian terhadap analisis CAMEL kemudian dituangkan dalam bentuk angka yang diberikan bobot sesuai dengan ketentuan yang telah ditetapkan. Bobot nilai ini diartikan sebagai nilai kredit. Dari bobot nilai ini dapat dipastikan kondisi suatu bank. Batas minimal dan maksimal untuk menentukan predikat suatu bank dapat dilihat dalam tabel berikut ini. (Kasmir, 2004, hal. 44-45)

Tabel 2. Nilai Kredit Penilaian Tingkat Kesehatan Bank Berdasarkan Metode CAMEL

\begin{tabular}{cc}
\hline Nilai Kredit & Predikat \\
\hline $81-100$ & Sehat \\
\hline $66-<81$ & Cukup Sehat \\
\hline $51-<66$ & Kurang Sehat \\
\hline $0-<51$ & Tidak Sehat \\
\hline
\end{tabular}




\subsection{PENDEKATAN RGEC}

Metode RGEC merupakan turunan dari Peraturan Bank Indonesia Nomor 13/1/PBI/2011 tentang penilaian tingkat kesehatan Bank Umum berdasarkan profil risiko. Indikator penilaian yang ada dalam penilaian tingkat kesehatan bank syariah dan unit syariah dipaparkan dalam Surat Edaran OJK Nomor 10/SEOJK.03/2014 sebagai berikut:

\subsubsection{Penilaian Faktor Profil Risiko}

Penilaian faktor Profil Risiko merupakan penilaian terhadap Risiko inheren dan kualitas penerapan Manajemen Risiko dalam aktivitas operasional Bank. Risiko yang wajib dinilai terdiri atas 10 (sepuluh) jenis Risiko yaitu Risiko Kredit, Risiko Pasar, Risiko Likuiditas, Risiko Operasional, Risiko Hukum, Risiko Stratejik, Risiko Kepatuhan, Risiko Reputasi, Risiko Imbal Hasil, dan Risiko Investasi.

\subsubsection{Penilaian Faktor Good Corporate Governance (GCG)}

Penilaian faktor Good Corporate Governance bagi Bank Umum Syariah merupakan penilaian terhadap kualitas manajemenbank atas pelaksanaan 5 (lima) prinsip Good Corporate Governance yaitu transparansi, akuntabilitas, pertanggungjawaban, profesional, dan kewajaran. Prinsip-prinsip Good Corporate Governance dan fokus penilaian terhadap pelaksanaan prinsipprinsip Good Corporate Governance tersebut berpedoman pada ketentuan Good Corporate Governance yang berlaku bagi Bank Umum Syariah dengan memperhatikan karakteristik dan kompleksitas usaha bank.

\subsubsection{Penilaian Faktor Rentabilitas}

Penilaian faktor Rentabilitas meliputi evaluasi terhadap kinerja Rentabilitas, sumber-sumber Rentabilitas, kesinambungan (sustainability) Rentabilitas, manajemen Rentabilitas, dan pelaksanaan fungsi sosial. Dalam PBI No 13/1/PBI/2011 Tentang Penilaian Kesehatan Bank Umum untuk mengukur rentabilitas dapat menggunakan rasio ROA (Return On Asset) dan NOM (Net Operating Margin).

\subsubsection{Penilaian Faktor Permodalan}

Penilaian faktor Permodalan meliputi evaluasi terhadap kecukupan modal dan kecukupan pengelolaan Permodalan. Dalam melakukan perhitungan Permodalan, Bank Umum Syariah mengacu pada ketentuan yang berlaku mengenai kewajiban penyediaan modal minimum bagi Bank Umum Syariah. Untuk mengukur penilaian permodalan rasio yang digunakan adalah Rasio CAR (Capital Adequency Ratio).

Tabel 3. Peringkat Komposit Tingkat Kesehatan Bank dengan Pendekatan Risk-Based Bank Rating (RBBR)

\begin{tabular}{cc}
\hline Peringkat Komposit & Keterangan \\
\hline PK 1 & Sangat Sehat \\
\hline PK 2 & Sehat \\
\hline
\end{tabular}




\begin{tabular}{cc}
\hline PK 3 & Cukup Sehat \\
\hline PK 4 & Kurang Sehat \\
\hline PK 5 & Tidak Sehat \\
\hline \multicolumn{2}{c}{ Sumber: Refmasari dan Setiawan (2014) }
\end{tabular}

Faktor-faktor yang dinilai dalam pendekatan CAMELS dan RGEC dapat dilihat pada tabel berikut

Tabel 4. Faktor-faktor yang dinilai dalam pendekatan CAMELS dan RGEC

\begin{tabular}{|c|c|c|c|}
\hline $\mathrm{NO}$ & \multicolumn{2}{|c|}{ CAMELS } & RGEC \\
\hline 1. & \multicolumn{2}{|c|}{ Permodalan (Capital) } & Permodalan (Capital) \\
\hline 2. & \multicolumn{2}{|l|}{ Aset } & Profil Resiko Kredit \\
\hline \multirow[t]{3}{*}{3.} & \multirow[t]{3}{*}{ Manajemen } & Secara Umum & GCG \\
\hline & & Kepatuhan & Profil Resiko Kepatuhan \\
\hline & & Manajemen Resiko & $\begin{array}{l}\text { Penilaian terhadap } \\
\text { manajemen resiko }\end{array}$ \\
\hline 4. & \multicolumn{2}{|c|}{ Rentabilitas (Earning) } & Rentabilitas (Earning) \\
\hline 5. & \multicolumn{2}{|l|}{ Likuiditas } & Profil Resiko Likuiditas \\
\hline 6. & \multicolumn{2}{|c|}{ Sensitifitas terhadap Resiko Pasar } & Profil Resiko Pasar \\
\hline
\end{tabular}

\section{METODE PENELITIAN}

Penelitian ini memiliki ruang lingkup bersifat mikroekonomi yaitu PT Bank Maybank Syariah. Penelitian ini bertujuan untuk menilai tingkat kesehatan keuangan Bank Maybank Syariah. Analisis yang digunakan adalah dengan cara menilai rasio keuangan yang dipublikasikan oleh bank berupa analisis deskriptif yang disajikan mulai tahun 2011 sampai dengan tahun 2016. Tingkat kesehatan keuangan bank diatas dianalisis menggunakan metode CAMEL (Capital, Assets, Management, Earnings, Liquidity) adapun variabel data kuantitatif yang digunakan untuk melihat kesehatan keuangan bank menggunakan rasio CAR untuk capital, rasio NPM untuk management quality serta ROA dan NOM untuk faktor earning. Rasio FDR untuk melihat likuiditas bank Sedangkan dalam metode RGEC(Risk Profile, Good Corporate Governance, Earnings dan Capital) atau disebut dengan RBBR variabel data kuantitatif yang digunakan sama dengan metode CAMEL, berbeda pada variabel data kualitatifnya.

Jenis penelitian yang dilakukan menggunakan penelitian kepustakaan atau disebut Penelitian Meja (Desk Study). Untuk penelitian dalam jenis ini peneliti menggunakan data yang sudah tersedia yang didapatkan dari berbagai media cetak dan maupun elektronik (Tanjung \& Devi, 2013). Sehingga peneliti tidak perlu mencari data melalui survey ataupun observasi 
di lapangan. Penelitian ini menggunakan data sekunder baik yang bersifat kualitatif maupun kuantitatif. Data tersebut diperoleh dari studi pustaka, jurnal, internet serta literatur lainnya yang terkait dengan penelitian. Data kuantitatif yang digunakan dalam penelitian imi adalah laporan keuangan Bank Maybank syariah periode 2011-2016 dan Laporan Good Corporate Governance.

Penelitian ini bertujuan untuk membandingkan kesehatan keuangan Bank Maybank Syariah menggunakan dua metode yang berbeda yaitu metode CAMELS dan metode RGEC. Secara umum kesehatan keuangan bank dapat diproyeksikan menggunakan rasio keuangan seperti dalam faktor capital, asset, earning dan liquidity. Metode yang digunakan dalam penelitian ini menggunakan analisis deskriptif dengan membandingkan metode penilaian kesehatan keuangan bank kemudian menganalisa laporan keuangan bank tersebut dengan menggunakan pendekatan CAMEL dan RGEC.

\section{HASIL DAN PEMBAHASAN}

\subsection{METODE CAMEL}

Penilaian tingkat kesehatan bank dengan mengunakan Metode CAMEL merupakan metode untuk menilai tingkat kesehatan bank secara kualitatif dan kuantitatif berdasarkan 5 aspek yaitu capital (permodalan), asset (kualitas aset), management (manajemen), earning (rentabilitas), liquidity (likuiditas), Dalam menganalisa penilaian tingkat kesehatan bank dengan menggunakan metode CAMEL penulis hanya membahas dari sisi finansialnya saja, sehingga indikator yang dinilai oleh penulis hanya pada faktor penilaian permodalan, kualitas aset, rentabilitas dan likuiditas.

\subsubsection{Permodalan (capital)}

Untuk menganalisa tingkat kesehatan bank dilihat dari indikator permodalannya dapat dilihat dari laporan keuangan yang dipublikasikan oleh Maybank Syariah melaui rasio CAR (Capital Adequacy Ratio). CAR mencerminkan modal sendiri perusahaan, semakin tinggi nilai CAR berarti semakin tinggi modal sendiri untuk membiayai aktiva produktif dan semakin rendah biaya yang dikeluarkan oleh bank. Adanya penurunan CAR disebabkan oleh penurunan modal terhadap kenaikan ATMR. Kenaikan ATMR terjadi karena kredit yang disalurkan oleh bank, semakin besar kredit yang diberikan oleh bank maka semakin besar ATMR bank sehingga CAR akan turun. Dapat dilihat rasio CAR bank Maybank Syariah pada tabel 1.

Berdasarkan hasil perhitungan rasio permodalan Bank Maybank Syariah selama lima tahun periode 2012-2016 secara berturut-turut adalah $63,89 \%, 59,41 \%, 52,13 \%, 38,40 \%, 55,06 \%$. Dari data diatas dapat dilihat bahwa rasio CAR Bank Maybank Syariah menurun setiap tahunnya dari tahun 2012 hingga tahun 2015. Penurunan drastis terjadi pada tahun 2015 dimana rasio CAR sebesar 38,40\% namun pada tahun 2016 Bank Maybank 
Syariah mampu meningkatkan kecukupan penyedian modalnya, walaupun terjadi penurunan CAR setiap tahunnya rasio CAR Bank Maybank Syariah berada pada interval $10 \%>\mathrm{KPMM}>12 \%$ sehingga rasio permodalannya dapat dikategorikan sangat sehat serta menunjukkan bahwa kemampuan Bank Maybank Syariah dalam menyerap kerugian dan mengelola kecukupan permodalannya dengan baik.

Berdasarkan table 1, peringkat kesehatan Bank Maybank Syariah dilihat dari komponen permodalannya memperoleh peringkat komposit 1 atau mendapatkan predikat sangat baik, karena memiliki rasio CAR melebihi standar minimal Bank Indonesia yaitu 8\%.

\subsubsection{Kualitas Aset}

Penilaian kualitas asset dilakukan untuk mengevaluasi kondisi aset bank dan untuk mengantisipasi risiko gagal bayar dari pembiayaan. Indikator yang digunakan untuk menilai kualitas asset adalah dengan menggunakan penilaian kualitas aktiva produktif yaitu dengan rasio KAP. Rasio KAP diperoleh dari aktiva produktif yang diklasifikasikan terhadap aktiva produktif.

Tabel 5. Rasio KAP Bank Maybank Syariah 2011-2016

\begin{tabular}{ccccccc}
\hline & 2011 & 2012 & 2013 & 2014 & 2015 & 2016 \\
\hline Rasio & $1,17 \%$ & $1,86 \%$ & $2,54 \%$ & $1,71 \%$ & $28,92 \%$ & $41,17 \%$ \\
\hline \multicolumn{7}{c}{ Sumber: Data diolah }
\end{tabular}

Berdasarkan tabel 5 diatas menunjukan bahwa rasio KAP Bank Maybank Syariah selama periode penelitian berubah secara fluktuatif. Dari tahun 2011-2012 rasio KAP mengalami peningkatan sebesar 0,69\% kemudian pada tahun 2013 mengalami peningkatan sebesar 0,68\%, kemudian mengalami penurunan kembali pada tahun 2014, penurunan pada tahun 2014 disebabkan terjadinya penurunan APYD dibanding tahun sebelumnya yang tidak sebanding dengan peningkatan aktiva produktifnya. Hal ini terjadi dikarenakan dana pada aktiva produktif tidak disalurkan sehingga menyebabkan pendapatan bank menurun. Pada tahun 2015-2016 rasio KAP mengalami peningkatan yang tinggi setiap tahunnya, tahun 2015 rasio KAP meningkat hingga 26,58\% dan pada tahun 2016 mengalami peningkatan kembali hingga sebesar $12,25 \%$. Peningkatan tertinggi berada pada tahun 2016 yaitu nilai rasio sebesar 41,17\% hal ini menunjukan bahwa terjadi karena jumlah APYD berimbang terhadap peningkatan aktiva produktif.

\subsubsection{Manajemen}

Kualitas manajemen berfungsi untuk menilai kemampuan manajerial pengurus bank dalam menjalankan usaha sesuai dengan prinsip manajemen umum, kecukupan manajemen risiko dan kepatuhan bank terhadap ketentuan baik yang terkait dengan prinsip kehati-hatian maupun kepatuhan terhadap prinsip syariah dan komitmen bank kepada Bank Indonesia dengan mengajukan kuesioner terkait manajemen umum maupun manajemen resiko 
namun dalam penelitian ini penilaian sistem manajemen kuesioner tidak dapat diterapkan karena kerahasian bank maka kualitas manajemen diproyeksikan dengan perhitungan rasio Net Profit Margin sebagai berikut:

Tabel 6. Rasio NPM Bank Maybank Syariah 2011-2016

\begin{tabular}{ccccccc}
\hline & 2011 & 2012 & 2013 & 2014 & 2015 & 2016 \\
\hline NPM & $87,59 \%$ & $150 \%$ & $134 \%$ & $164 \%$ & $-1,274 \%$ & $-410 \%$ \\
\hline
\end{tabular}

Sumber: Data Diolah

Rasio NPM berfungsi untuk menunjukkan kemampuan perusahaan dalam menghasilkan keuntungan bersih. Rasio ini diperoleh dengan membandingkan laba bersih terhadap pendapatan operasional bank. Pada tahun 2011 rasio NPM menunjukan sebesar 87,59 dimana angka ini berada pada interval $81 \% \leq \mathrm{NPM}<100 \%$ dimana hal tersebut menunjukan bahwa kondisi NPM berada pada posisi sehat. Pada tahun 2012-2014 kondisi NPM bank menunjukkan bahwa selama 3 tahun berturut turut rasio NPM berada pada angka lebih dari $100 \%$ dimana hal tersebut menunjukan bahwa kondisi bank berada pada kondisi yang sangat sehat, sementara pada tahun 20152016 kondisi kesehatan bank berada dibawah 50\% yang artinya kondisi NPM bank berada pada posisi yang tidak sehat.

\subsubsection{Rentabilitas (earning)}

Komponen penilaian rentabilitas terdiri dari penilaian rasio ROA (Return On Asset) yaitu rasio laba terhadap aset dan rasio BOPO yaitu rasio beban operasional terhadap pendapatan. Penilaian faktor rentabilitas dilakukan untuk mengetahui tingkat kemampuan bank dalam memperoleh keuntungan.

Rasio ROA digunakan untuk mengukur kemampuan bank memperoleh laba sebelum pajak. Semakin besar nilai ROA maka semakin besar pula keuntungan yang dicapai oleh bank. Nilai ROA Bank Maybank Syariah dapat dilihat pada tabel 6 diatas.

Berdasarkan tabel diatas menunjukan bahwa dari tahun 2011 sampai dengan tahun 2016 nilai ROA Bank Maybank Syariah berubah secara fluktuatif. Pada tahun 2012 nilai ROA turun sebesar 0,69 \% menjadi 2,88\% dan meningkat $0,01 \%$ pada tahun 2013. Peningkatan ROA tertinggi selama periode penelitian terjadi pada tahun 2014 dimana nilai ROA sebesar 3,61\%. Peringkat komposit ROA yang dimiliki oleh Bank Maybank Syariah dari tahun 2011-2014 dinilai sangat sehat karena melebihi dari kriteria penilaian yang ditetapkan oleh BI yaitu 1,215\%, sedangkan pada tahun 2015 dan 2016 Bank Maybank Syariah mengalami penurunan ROA yang sangat drastis pada tahun 2015 diketahui nilai ROA adalah $-20,13 \%$ ini menunjukan bahwa rasio ROA berada pada posisi yang tidak sehat karena berada kurang dari nilai yang ditetapkan oleh BI yaitu $0,765 \%$.Selanjutnya dalam penilaian komponen rentabilitas faktor yang harus dinilai merupakan rasio BOPO. Analisis rasio BOPO merupakan hasil analisis beban operasional terhadap pendapatan operasional, semakin rendah tingkat rasio BOPO berarti semakin 
baik kinerja manajemen bank tersebut, Karena lebih efisien dalam menggunakan sumber daya yang ada di perusahaan.

Berdasarkan tabel diatas menunjukkan bahwa BOPO Bank Maybank Syariah selama masa periode penelitian memiliki nilai yang fluktuatif. Pada tahun 2012 BOPO mengalami penurunan sebesar 1,41\%. Penurunan BOPO diindikasikan terjadi karena adanya peningkatan tingkat efisiensi dalam menggunakan sumber daya yang ada pada perusahaan. Semakin kecil rasio BOPO pada bank maka semakin baik dikarenakan biaya yang dikeluarkan oleh bank terhadap usaha yang dijalankan efisien sehingga dengan biaya yang dikeluarkan bank mampu mendapatkan hasil yang baik.

Pada tahun 2013 hingga tahun 2015 rasio BOPO mengalami peningkatan setiap tahunnya berturut-turut. Kenaikan tertinggi berada pada tahun 2015 dimana nilai BOPO mencapai 192,60\% mengalami kenaikan sebesar 122,98\% dengan nilai tersebut dapat diindikasikan bahwa nilai BOPO berada pada posisi yang tidak sehat. Peningkatan nilai BOPO terjadi karena adanya penurunan efisiensi dalam memanfaatkan sumber daya yang ada pada perusahaan. Pada tahun 2016 nilai BOPO mengalami penurunan hingga 32,32\% namun masih dalam posisi yang membahayakan karena nilai BOPO Bank Maybank Syariah masih berada diatas ketentuan yang ditetapkan oleh bank yaitu lebih dari $95,92 \%$ sementara nilai BOPO bank adalah sebesar $160,28 \%$

\subsubsection{Likuiditas}

Komponen faktor likuiditas meliputi kewajiban bersih antar bank yaitu selisih antara kewajiban bank dengan tagihan kepada bank lain dan modal inti bank, selain kewajiban bersih faktor yang diperlukan untuk menilai likuiditas adalah rasio FDR (Financing to Deposit Ratio) rasio FDR adalah perbandingan total pembiayaan yang diberikan dengan total Dana Pihak Ketiga yang dapat dihimpun oleh bank. FDR akan menunjukan tingkat kemampuan bank dalam menyalurkan dana pihak ketiga yang dihimpun oleh bank yang bersangkutan. (Ryadi, 2004)

Berdasarkan data tabel diatas besarnya FDR yang disalurkan oleh Bank Maybank Syariah tersebut rata-rata melebihi batas yang ditentukan oleh Bank Indonesia yaitu 115\%. Kondisi FDR Bank Maybank Syariah selama periode penelitian memiliki nilai yang fluktuatif, pada tahun 2011-2013 mengalami penurunan setiap tahunnya pada tahun 2012 mengalami penurunan sebesar 91,5\% dan pada tahun 2013 mengalami penurunan sebesar $44,83 \%$, meskipun mengalami penurunan setiap tahunnya nilai FDR masih berada di kondisi yang tidak sehat karena masih melebihi diatas batas yang ditentukan oleh Bank Indonesia. Pada tahun 2014 FDR mengalami peningkatan sebesar 4,83\%, kemudian mengalami penurunan sebesar 47,16 $\%$ pada tahun 2015 pada tahun ini nilai FDR berada dibawah 115\% dan mengalami peningkatan kembali pada tahun 2016 yaitu sebesar 24,19\%. Jika nilai FDR melebihi nilai $100 \%$ menunjukan bahwa fungsi bank sebagai lembaga intermediasi, yaitu lembaga yang menghubungkan antara pihak yang kelebihan dana dengan pihak yang membutuhkan dana belum berfungsi 
dengan baik. Selanjutnya untuk menilai tingkak kesehatan bank pada komponen likuiditas dapat menggunakan rasio kewajiban bersih antar bank terhadap modal inti. Kewajiban bersih yang dimaksud adalah selisih antara kewajiban dengan tagihan kepada bank lain. Berikut ini merupakan rasio kewajiban bersih terhadap modal inti Bank Maybank Syariah periode 20112016:

Tabel 7. Rasio Kewajiban Bersih Terhadap Modal Inti Bank Maybank Syariah 2011-2016

\begin{tabular}{ccccccc}
\hline & 2011 & 2012 & 2013 & 2014 & 2015 & 2016 \\
\hline Rasio & $73,08 \%$ & $63,83 \%$ & $26,81 \%$ & $21,09 \%$ & $118,2 \%$ & $90,29 \%$ \\
\hline \multicolumn{6}{c}{ Sumber: Data diolah }
\end{tabular}

Berdasarkan data Rasio kewajiban bersih terhadap modal inti Bank Maybank Syariah selama periode 2011-2016 bernilai fluktuatif setiap tahunnya. Data diatas menunjukan bahwa rasio terkecil berada pada tahun 2014 yaitu sebesar $21,09 \%$ dan rasio terbesar berada pada tahun 2015 yaitu $118 \%$. Semakin kecil rasio kewajiban bersih terhadap modal inti maka likuiditas bank semakin baik karena bank dapat menutupi kewajiban terhadap bank lain, sebaliknya semakin besar rasio ini maka semakin tidak likuid kondisi bank.

\subsection{PENILAIAN TINGKAT KESEHATAN BANK MENURUT METODE RGEC}

Penilaian tingkat kesehatan dengan metode ini selain dilihat dari indikator finansialnya juga dilihat dari indikator risikonya. Adapun indikator penilaian kesehatan bank dengan menggunakan metode RGEC adalah penilaian terhadap Risk Profile (profil risiko), Good Corporate Governance (GCG), Earning (rentabilitas), dan Capital (permodalan).

\subsubsection{Profil Risiko}

Merupakan penilaian terhadap risiko inheren dalam aktivitas operasional bank syariah. Terdapat sepuluh risiko dalam risiko inheren, namun penelitian ini profil risiko yang diukur menggunakan hanya menggunakan dua aspek risiko dikarenakan tidak terdapat data kuantitatif yang disediakan dari delapan risiko lainnya. Dua aspek risiko tersebut adalah aspek risiko kredit dengan menggunakan Rasio Non Performing Financing (NPF) dan aspek risiko likuiditas dengan menggunakan Rasio Financing to Deposit Ratio (FDR). Rasio NPF dapat dilihat pada tabel 1 diatas.

NPF merupakan rasio yang menunjukkan kemampuan bank dalam mengelola kredit bermasalah. Berdasarkan perhitungan NPF yang didapat dari tahun 2011-2013 NPF Bank Maybank Syariah berada pada tingkat yang aman karena masih jauh berada dibawah nilai yang ditentukan oleh Bank Indonesia yaitu pada Peringkat Komposit-1 (PK-1) $<7 \%$ bahkan pada tahun 2011 diketahui bahwa nilai NPF Bank Maybank syariah sebesar 0\%. Pada tahun 2014-2016 tingkat NPF berada pada angka 4\% angka tersebut menunjukan bahwa tingkat NPF Bank Maybank Syariah masih dalam 
kategori. Kenaikan tertinggi berada pada tahun 2015 ketika rasio NPF mengalami kenaikan hingga $0,64 \%$ menjadi $4,93 \%$. Semakin tinggi nilai NPF maka semakin tinggi tunggakan kredit yang dapat menurunkan pendapatan, sebaliknya semakin turun nilai NPF nya maka dapat membuktikan bahwa bank tersebut mampu mengatasi kredit bermasalah yang terjadi sehingga kredit yang disalurkan justru berpotensi menambah pendapatan. (Kusumawardani, 2014) Berdasarkan penyajian data diatas menunjukan bahwa baiknya pengelolaan risiko kredit pada kredit yang diklasifikasikan kurang lancar, dalam perhatian khusus maupun macet namun kredit yang diberikan terus meningkat. Selanjutnya merupakan penilaian aspek risiko likuiditas dengan menggunakan rasio FDR

Berdasarkan tabel 1 di atas menunjukkan bahwa rasio FDR Bank Maybank Syariah berada pada tingkat peringkat komposit 5 dari tahun 2011 sampai 2014 kemudian menurun sebesar 47,16\% pada tahun 2015 menjadi sebesar 110,54\% namun angka ini masih berada di posisi yang kurang baik karena masih berada di peringkat komposit 4. Pada tahun 2016 FDR Bank Maybank syariah kembali berada di peringkat komposit 5, meningkat dengan FDR sebesar $134,73 \%$.

\subsubsection{Good Corporate Governance}

Penilaian Good Corporate Governance (GCG) dilakukan secara self assesment dimana bank melakukan penilaian sendiri atas kinerjanya selama satu tahun dengan mengkaji beberapa faktor penilaian. Berdasarkan penelitian Akindele (2012), GCG dan manajemen risiko saling berkaitan dalam mempengaruhi kinerja suatu bank. Oleh sebab itu hasil kinerja dari bank bergantung pada penilaianmanajemen risiko dan GCG (Dwinanda \& Wiagustini)

Tabel 8. Peringkat Good Corporate Governace Periode 2011-2016

\begin{tabular}{ccccccc}
\hline & 2011 & 2012 & 2013 & 2014 & 2015 & 2016 \\
\hline GCG & 1 & 2 & 2 & 2 & 3 & 3 \\
\hline
\end{tabular}

Sumber: Laporan GCG Bank Maybank Syariah 2011-2016

Kondisi GCG bank dari tahun 2011-2016 mengalami penurunan pada tahun 2011 GCG berada pada posisi tertinggi yaitu peringkat komposit 1 dimana hal tersebut menunjukan bahwa kondisi bank berada pada predikat sangat baik. Pada tahun 2012-2014 GCG bank berada pada peringkat komposit 2 pada rentang tahun tersebut GCG mengalami penurunan satu peringkat dibandingkan tahun sebelumnya. Predikat GCG bank pada rentang tahun tersebut adalah sehat. Pada tahun 2015-2016 kondisi GCG bank berada pada peringkat komposit 3 hal ini menunjukan bahwa kondisi bank berada pada predikat yang cukup sehat.

\subsubsection{Rentabilitas (Earnings)}

Penilaian indikator rentabilitas menggunakan dua rasio keuangan yaitu rasio ROA (Return On Asset) dan rasio NOM (Net Operating Margin), rasio 
rentabilitas digunakan untuk mengetahui kemampuan bank mendapatkan laba. Rasio ROA digunakan untuk mengukur kemampuan bank memperoleh laba sebelum pajak. Semakin besar nilai ROA maka semakin besar pula keuntungan yang dicapai oleh bank. Nilai ROA Bank Maybank Syariah dapat dilihat dalam tabel 1 diatas

Berdasarkan tabel diatas menunjukan bahwa dari tahun 2011 sampai dengan tahun 2016 nilai ROA Bank Maybank Syariah berubah secara fluktuatif. Pada tahun 2012 nilai ROA turun sebesar 0,69\% menjadi 2,88\% dan meningkat $0,01 \%$ pada tahun 2013. Peningkatan ROA tertinggi selama periode penelitian terjadi pada tahun 2014 dimana nilai ROA sebesar 3,61\%. Peringkat komposit ROA yang dimiliki oleh Bank Maybank Syariah dari tahun 2011-2014 dinilai sangat sehat karena melebihi dari kriteria penilaian yang ditetapkan oleh BI yaitu 1,215\%, sedangkan pada tahun 2015 dan 2016 Bank Maybank Syariah mengalami penurunan ROA yang sangat drastis pada tahun 2015 diketahui nilai ROA adalah $-20,13 \%$ ini menunjukan bahwa rasio ROA berada pada posisi yang tidak sehat karena berada kurang dari nilai yang ditetapkan oleh BI yaitu $0,765 \%$.

Selanjutnya hasil analisis Net Operating Margin (NOM) pada Bank Maybank Syariah dapat dilihat pada tabel 1. NOM (Net Operating Margin), rasio ini berfungsi untuk mengetahui kemampuan aktiva produktif dalam menghasilkan laba. Semakin besar nilai rasio ini maka pendapatan dari aktiva produktif yang dikelola oleh bank semakin tinggi, sehingga kemungkinan bank mengalami kesulitan keuangan semakin kecil. Nilai rasio NOM Bank Maybank Syariah tahun 2014-2016 berada dibawah batas yang ditentukan oleh Bank Indonesia yaitu pada tahun 2014 sebesar $-1,46 \%$ kemudian pada tahun 2015 kembali mengalami penurunan $31,46 \%$ dan mengalami peningkatan pada tahun 2016 sebesar 12,96 meskipun masih berada dibawah batas yang ditentukan oleh Bank Indonesia, artinya kondisi laba bank berada pada kondisi yang tidak sehat dan kemampuan rentabilitas bank tidak mampu untuk mengantisipasi kerugian yang mungkin terjadi

\subsubsection{Permodalan (Capital)}

Penilaian pada faktor permodalan didasarkan kepada permodalan yang dimiliki oleh suatu bank. Salah satu indikator dalam menilai tingkat kesehatan bank salah satunya menggunakan perhitungan rasio CAR (Capital Adequacy Ratio) yaitu dengan cara membandingkan jumlah modal setelah dikurangi penyertaan terhadap aktiva tertimbang menurut resiko. (Kasmir, 2000, hal. 185) Rasio permodalan digunakan untuk menghitung apakah modal yang ada pada bank mencukupi atau tidak. Penilaian faktor permodalan berpedoman pada ketentuan Bank Indonesia tentang Kewajiban Penyediaan Modal Minimum (KPMM) bank umum berdasarkan prinsip syariah yang berlaku.

Berdasarkan tabel 1 diatas rasio CAR pada tahun 2011 sampai dengan tahun 2016 bahwa Bank Maybank Syariah memiliki nilai CAR diatas batas minimal yaitu $8 \%$. Dengan ini menunjukkan bahwa modal yang dimiliki oleh bank dapat menutupi penurunan aktiva sebagai akibat dari kerugian yang 
disebabkan oleh aktiva meskipun pada tahun 2011 hingga tahun 2015 nilai CAR bank cenderung semakin menurun. Penurunan CAR terjadi sebagai akibat dari peningkatan jumlah ATMR yang lebih tinggi dibandingkan dengan peningkatan total modal, namun pada tahun 2016 bank mampu meningkatkan rasio pemodalannya hingga $16,66 \%$. Peningkatan CAR terjadi akibat peningkatan jumlah modal yang lebih tinggi dibandingkan dengan peningkatan jumlah ATMR. Adapun nilai CAR tertinggi berada pada tahun 2011 dimana nilai rasio CAR sebesar 73,44\%.

Berdasarkan nilai rasio CAR yang dimiliki oleh Bank Maybank Syariah pada tahun 2011 sampai dengan 2016 menunjukkan bahwa nilai kredt CAR lebih besar dibandingkan dengan batas minimum yang ditetapkan oleh Bank Indonesia. Maka rasio yang dicapai oleh Bank Maybank Syariah dikategorikan dalam kelompok Sehat.

\subsection{METODE YANG MENILAI LEBIH BAIK}

Pada penilaian tingkat kesehatan bank dengan menggunakan metode CAMEL lebih terfokus pada sisi pencapaian laba sehingga Kualitas Aktiva Produktif harus dihitung selain komponen yang disebutkan diatas. Kualitas Aktiva Produktif ini juga memiliki peran yang besar dalam penilaian menggunakan metode ini yaitu sebesar $25 \%$ dari keseluruhan komponen. Penilaian komponen faktor pada metode CAMEL selanjutnya ditarik kesimpulan dengan pemberian nilai bobot pada tiap tiap komponen kemudian hasil dari keseluruhan bobot atau disebut nilai kredit diberi predikat sehat, cukup sehat, kurang sehat dan tidak sehat.

Berbeda dengan metode CAMEL penilaian tingkat kesehatan bank dengan menggunakan metode RGEC terfokus pada penilaian risiko tidak hanya pada sisi pencapian laba saja sehingga pada metode ini penilaian tingkat kesehatan bank dilakukan secara menyeluruh baik dari penilaian profil risiko maupun dari sisi pencapaian laba. Profil risiko sendiri memiliki 10 kategori yang harus dinilai yaitu diantaranya risiko kredit, risiko pasar, risiko likuiditas, risiko operasional, risiko hukum, risiko stratejik, risiko kepatuhan, risiko reputasi, risiko imbal hasil dan risiko investasi. Penilaian komponen faktor dengan menggunakan metode RGEC ini kemudian ditarik kesimpulan dengan pemberian peringkat pada masing-masing komponen dan pemberian peringkat komposit dari peringkat 1 sampai dengan 5 atau predikat sangat sehat, sehat, cukup sehat, kurang sehat dan tidak sehat. Berikut hasil penilaian tingkat kesehatan Bank Maybank Syariah periode 2011-2016 dengan menggunakan metode CAMEL dan RGEC:

Tabel 9. Predikat Tingkat Kesehatan Bank Maybank Syariah Periode 20112016

\begin{tabular}{ccc}
\hline \multirow{2}{*}{ Periode } & \multicolumn{2}{c}{ Predikat } \\
\cline { 2 - 3 } & CAMEL & RGEC \\
\hline 2011 & Cukup Sehat & Sehat \\
\hline 2012 & Cukup Sehat & Sehat \\
\hline
\end{tabular}




\begin{tabular}{ccc}
\hline 2013 & Cukup Sehat & Sehat \\
\hline 2014 & Cukup Sehat & Cukup Sehat \\
\hline 2015 & Tidak Sehat & Cukup Sehat \\
\hline 2016 & Tidak Sehat & Cukup Sehat \\
\hline
\end{tabular}

Sumber: Data diolah

Berdasarkan tabel diatas dapat disimpulkan bahwa penilaian tingkat kesehatan dengan menggunakan kedua metode tersebut memiliki hasil yang sangat berbeda. Pada tahun 2011 tingkat kesehatan bank menggunakan metode CAMEL menunjukan hasil yang cukup sehat sementara pada metode RGEC hasil yang didapatkan bahwa kondisi bank berada pada kondisi yang sehat, begitu pula pada tahun 2015 data diatas menunjukan bahwa penilaian tingkat kesehatan bank menggunakan metode CAMEL menunjukan bahwa bank berada pada kondisi yang tidak sehat sementara pada metode RGEC hasil yang diperoleh menunjukan bahwa bank berada pada posisi yang cukup sehat.

Pada penilaian CAMEL dapat disimpulkan bahwa apabila indikator kualitas aset dan likuiditas memiliki nilai yang tidak baik maka dapat diprediksi bahwa keadaan bank tersebut berada pada posisi yang tidak sehat, namun pada penilaian tingkat kesehatan bank dengan menggunakan metode RGEC apabila indikator profil risiko atau rentabilitas memiliki nilai yang tidak baik maka belum tentu keadaan bank berada pada posisi yang tidak sehat selama penanganan risiko yang dimiliki bank baik sehingga dianggap mampu meminimalisir risiko.

Bank Maybank Syariah sendiri melakukan penilaian tingkat kesehatan bank menggunakan metode Risk Based Bank Rating atau disebut RBBR yang kemudian dalam penelitian ini disebut metode RGEC. Bank Maybank Syariah sendiri terbentuk pada tahun 2010 dimana pada tahun tersebut metode penilaian kesehatan bank masih menggunakan metode CAMEL dimana metode RGEC baru diterapkan pada tahun 2011 dengan dikeluarkannya Peraturan Bank Indonesia nomor 13/1/PBI/2011 tentang penilaian kesehatan bank berdasarkan resiko, artinya Bank Maybank Syariah mengalami penilaian kesehatan bank menggunakan kedua metode tersebut. Menurut Maybank Syariah sendiri diantara kedua metode tersebut, metode yang dianggap menilai lebih baik adalah metode RGEC karena indikator yang terdapat dalam metode tersebut lebih detail dibandingkan dengan metode CAMEL yang memang hanya terfokus pada pencapaian laba dan keadaan keuangan bank. (Apriani, 2017) Sementara pada metode RGEC apabila terjadi masalah pada salah satu indikator penilaian tingkat kesehatan bank, selama masalah tersebut dapat diminimalisir melalui manajemen profil risiko maka kondisi bank tersebut masih berada pada posisi yang sehat.

Fahmi dan Husnah dalam penelitiannya menggambarkan bahwa penilaian metode RGEC lebih komprehensif karena pada metode ini menggabungkan faktor pada metode CAMEL yaitu aset dengan penilaian resiko kredit dan likuiditas dengan risiko likuiditas sedangkan manajemen 
diperluas penilaiannya dengan penilaian GCG pada Bank, dengan adanya penilaian kesehatan bank dengan menggunakan RGEC yang mengintegrasi faktor faktor yang terdapat pada metode CAMEL dan Manajemen Resiko diharapkan dapat memberikan gambaran jelas tentang kondisi bank yang tidak hanya dinilai dari kinerja internal bank semata, namun merupakan penilaian terhadap kualitas manajemen bank dalam melakukan manajemen resiko (Fahmi \& Hasanah, 2013)

\section{SIMPULAN}

Berdasarkan hasil analisis pada penelitian di atas, dapat ditarik kesimpulan bahwa penilaian tingkat kesehatan bank baik menggunakan metode CAMEL dan RGEC pada Bank Maybank Syariah Indonesia Periode 2011-2016 adalah sebagai berikut. Pada tahun 2011-2014 kondisi kesehatan Bank Maybank Syariah dihitung menggunakan metode CAMEL bank berada pada kategori yang Cukup sehat. Pada tahun 2015 -2016 hasil penghitungan tingkat kesehatan bank menggunakan metode CAMEL menunjukan bahwa kondisi bank berada pada posisi yang tidak sehat.Pada Bank Maybank Syariah keadaan bank berada pada kategori sehat berada pada tahun 2011-2013 jika dihitung menggunakan metode RGEC. Pada tahun 2014-2016 kondisi bank apabila dihitung menggunakan metode RGEC, bank berada pada kategori yang cukup sehat.

Dari kedua metode penilaian tingkat kesehatan bank Maybank Syariah periode 2011 sampai 2016 memiliki hasil yang berbeda hal ini dikarenakan pada metode CAMEL tata cara penilaian banyak difokuskan kepada pencapaian laba sedangkan pada metode RGEC terfokus pada peminimalisiran resiko yang mungkin terjadi. Diantara kedua metode tersebut, metode yang dinilai menilai lebih baik adalah metode RGEC Karena dapat melihat tingkat kesehatan bank secara menyeluruh melalui resiko-resiko yang mungkin terjadi tidak hanya dilihat dari sisi keuangannya saja.

\section{DAFTAR PUSTAKA}

Apriani, D. K. (2017, September 14). Divisi Finance \& Accounting Maybank Syariah Indonesia. (A. C. Aprilianti, Interviewer) Wawancara Pribadi, Jakarta, 14 September 2017.

Dwinanda, I. A. W., \& Wiagustini, N. L. P. (2013). Analisis penilaian tingkat kesehatan bank pada PT. Bank Pembangunan Daerah Bali berdasarkan metode RGEC. E-Jurnal Akuntansi Universitas Udayana.

Fahmi, Adam dan Hasanah, Nurul. (2013). Analisis Perbandingan Penilaian Tingkat Kesehatan Bank Setelah dan Sebelum Dierlakukan PBI No. 
13/1/PBI/2011 (Studi Kasus PT Bank X). Jurnal Program S1 Ekstensi Akuntansi FEUI

Herman, D. (2011). Manajemen Perbankan, edisi keempat. Jakarta: Penerbit Bumi Aksara.

Ihsan \& Nuraini, Dwi. (2015). Manajemen Treasury. Tangerang: UIN Press

Kasmir. (2000). Manajemen Perbankan. Jakarta: PT RajaGrafindo Persada

Kasmir. (2004). Dasar-Dasar Perbankan. Jakarta: PT RajaGrafindo Persada

Kusumo, Y. A. (2008). Analisis Kinerja Keuangan Bank Syariah Mandiri Periode 2002-2007 (dengan Pendekatan PBI No. 9/1/PBI/2007). La_Riba, 2(1), 109-131.

Merkusiwati, N. K. L. A. (2007). Evaluasi Pengaruh CAMEL Terhadap Kinerja Perusahaan. Buletin Studi Ekonomi, 12(1), 100-108.

Nawawi, Ismail (2011). Perbankan Syariah. Jakarta: Kencana Prenada Media Group.

Ryadi, Selamet. (2004). Banking Assets And Liability Management. Jakarta: Lembaga Penerbit Fakultas Ekonomi Univesitas Indonesia

Tanjung, H., \& Devi, A. (2013). Metodologi Penelitian Ekonomi Islam. Jakarta, Gramata Publishing. 
